\title{
Phenotypic and Molecular Properties of the Nocardia Species
}

\author{
Mehdi Fatahi Bafghi ${ }^{1}$; Parvin Heidarieh ${ }^{2}$; Shadi Habibnia ${ }^{1}$; Masoumeh Rasouli Nasab ${ }^{1}$; \\ Davood Kalantar Neyestanaki ${ }^{3}$; Davoud Afshar ${ }^{1}$; Seyyed Saeed Eshraghi ${ }^{1{ }^{*}}$ \\ ${ }^{1}$ Department of Pathobiology, School of Public Health, Tehran University of Medical Sciences, Tehran, IR Iran \\ 2 Department of Bacteriology and Virology, School of Medicine, Alborz University of Medical Sciences, Karaj, IR Iran \\ 3 Department of Microbiology, School of Medicine, Kerman University of Medical Sciences, IR Iran \\ ${ }^{*}$ Corresponding author: Seyyed Saeed Eshraghi, Department of Microbiology, School of Public Health, Tehran University of Medical Sciences, Tehran, IR Iran. Tel:+98-2188994823, Fax: \\ +98-2188954913, E-mail: eshraghs@tums.ac.ir
}

Received: March 9, 2014; Accepted: March 9, 2014

Keywords: Nocardia; Biochemical Methods; Molecular Diagnostic Techniques

\section{Dear Editor,}

Nocardia spp are gram-positive aerobic, partially acid fast and filamentous bacteria that cause Nocardial infections (nocardiosis) in human. The genus Nocardia has slow-growth on various media and lives in environment such as soil, dust, sand and air (1-3). Nocardia identification at the species level is very important for four reasons: 1) to predict antimicrobial and anti-bacterial susceptibility 2) for epidemiological studies 3) to determine the final diagnosis that is necessary for treatment and 4) for geographic repartition (3-5). These bacteria cause infections in patients with immune disorder disease and immunecompetent individuals. Course of treatment in these patients is long (6) so correct identification of species is important. There are two methods for species identification in the genus Nocardia: 1) phenotypic and biochemical methods 2) molecular techniques. Phenotypic methods include factors such as colony morphology, Gram and partially acid fast staining, growth in lysozyme broth, growth at $45^{\circ} \mathrm{C}$, hydrolysis of casein, xanthine, hypoxanthine, esculin, adenine and gelatin, and the utilization of citrate, acetamide and various sugars $(2,5)$. The uses of phenotypic methods are time consuming, laborious and analysis of phenotypic tests needs skilled personals (4). The number of Nocardia spp are increasing, so accurate identification using phenotypic characteristics is difficult (6). In the recent years (1990s), various molecular methods such as 16S rRNA-restriction fragment length polymorphism (RFLP), HSP gene-RFLP, PCR-sequencing such as 16S rRNA (1500 regain), $65 \mathrm{kDa}$ heat shock proteins (TB11 and TB12 primers), gyrB (GYRBF1 and GYRBR1 primers) and sod (Z205 and Z212 primers) genes were used for more accurate identification of Nocardia species. For 16S rRNA-RFLP and HSP gene-RFLP analysis, restriction enzyme analysis (REA) is used, such as HinPII, SphI, BstEII, HindIII, DpnII, BsaHI, Hinfl and MspI (1-3, 6, 7). The results of several molecular techniques with phenotypic methods have been reported to be acceptable and appropriate for Nocardia species $(7,8)$. Wallace et al. during 1986, reported antimicrobial typing (six types) for some of the species. In this report various antimicrobial agents were used for Nocardia specious identification $(2,9)$. In summery the use of phenotypic and molecular methods is nessesary for Nocardia spp identification, specially Nocardia group complex.

\section{Acknowledgements}

We thanks of Tehran University of Medical Sciences, Deputy of Research.

\section{Authors' Contribution}

Mehdi Fatahi Bafghi contributed in designing, conducting and writing the manuscript; Parvin Heidarieh, designing and Writing the manuscript; Shadi Habibnia, conducting literature review the manuscript; Masoumeh Rasouli Nasab, conducting literature review the manuscript; Davood Kalantar Neyestanaki, conducting literature review the manuscript; Davoud Afshar, conducting literature review the manuscript; Seyyed Saeed Eshraghi, contributed in designing, conducting and Writing the manuscript.

\section{Financial Disclosure}

Paper has not financial disclosure.

\section{References}

1. Bafghi MF, Eshraghi SS, Heidarieh P, Habibnia SH, Rasouli Nasab M. Nocardiosis in Immune Disorder Disease. Malays J Med Sci. 2014;21(1):75-6.

Copyright ( 2014 , Hamadan University of Medical Sciences; Published by Safnek. This is an open-access article distributed under the terms of the Creative Commons Attribution License, which permits unrestricted use, distribution, and reproduction in any medium, provided the original work is properly cited. 
2. Brown-Elliott BA, Brown JM, Conville PS, Wallace RJ, Jr. Clinical and laboratory features of the Nocardia spp. based on current molecular taxonomy. Clin Microbiol Rev. 2006;19(2):259-82.

3. Rodriguez-Nava V, Couble A, Devulder G, Flandrois JP, Boiron P, Laurent F. Use of PCR-restriction enzyme pattern analysis and sequencing database for hsp65 gene-based identification of Nocardia species. J Clin Microbiol. 2006;44(2):536-46.

4. Kiska DL, Hicks K, Pettit DJ. Identification of medically relevant Nocardia species with an abbreviated battery of tests. J Clin Microbiol. 2002;40(4):1346-51.

5. Ambaye A, Kohner PC, Wollan PC, Roberts KL, Roberts GD, Cockerill FR, 3rd. Comparison of agar dilution, broth microdilution, disk diffusion, E-test, and BACTEC radiometric methods for antimicrobial susceptibility testing of clinical isolates of the Nocardia asteroides complex. J Clin Microbiol.1997;35(4):847-52.
6. Flateau C, Jurado V, Lemaitre N, Loiez C, Wallet F, Saiz-Jimenez $C$, et al. First case of cerebral abscess due to a novel Nocardia species in an immunocompromised patient. J Clin Microbiol. 2013;51(2):696-700.

7. Shojaei H, Hashemi A, Heidarieh P, Eshraghi S, Khosravi AR, Daei Naser A. Clinical isolation of Nocardia cyriacigeorgica from patients with various clinical manifestations, the first report from Iran. Med Mycol J. 2011;52(1):39-43.

8. Conville PS, Fischer SH, Cartwright CP, Witebsky FG. Identification of Nocardia species by restriction endonuclease analysis of an amplified portion of the 16S rRNA gene. J Clin Microbiol. 2000;38(1):158-64.

9. Wallace RJ, Jr., Steele LC, Sumter G, Smith JM. Antimicrobial susceptibility patterns of Nocardia asteroides. Antimicrob Agents Chemother.1988;32(12):1776-9. 